\title{
WOMEN IN ANTIQUITY: FROM MARGINALIZATION TO PROMINENCE
}

\author{
Etka Liebowitz*
}

\begin{abstract}
Despite the fact that royal women in Antiquity played a major dynastic role, historical accounts either ignored them or mentioned them merely as appendages to kings. Beginning in the 1970s, a major change transpired due to the impact of women's and gender studies. Numerous studies on the role of royal women in Antiquity were published, shedding light upon previously unknown women. This new understanding of royal women in Antiquity has implications for historical scholarship and its methodologies as well as for attitudes towards contemporary female leaders, who can be viewed as a continuation of an ancient tradition.
\end{abstract}

The escalating interest in royal women in Antiquity from the 1970s onwards has launched a plethora of studies bringing to light the varied roles and actions of royal women that were previously obscured.' This new knowledge has not only contributed to a better understanding of the role of women in Antiquity but also of the events and processes in which these women played a major role. June Hannam points out another effect of these historical studies:

The writing of women's history has always been closely linked with contemporary feminist politics as well as with changes in the discipline of history itself. When women sought to question inequalities in their own lives they turned to history to understand the roots of their oppression and to see what they could learn from challenges that had been made in the past. ${ }^{2}$

Looking back upon the past two centuries of scholarship, this article will examine the impact of women's and gender studies upon the scholarly evaluation of the role of royal women in Antiquity in general, and of Jewish aristocratic women in the Second Temple Period in particular. ${ }^{3}$ Such an investigation has implications for historical scholarship and its methodologies as well as for attitudes towards contemporary female leaders. Although one may claim that aristocratic women do not represent the majority of women, one must remember that the ordinary woman (and even man) was seldom mentioned in ancient texts. Therefore royal women lend themselves well to such an analysis due to their presence, even if minor, in ancient writings.

I would like to preface this analysis with an examination of the difference between women's and gender studies as they relate to the field of history. Women's studies commenced in force in the 1970s, focusing upon women as active agents in the historical narrative. ${ }^{.}$This new field involved reading

\footnotetext{
* Schechter Institute of Jewish Studies, Jerusalem, Israel. Email: etka.liebowitz@mail.huji.ac.il

For example, the Macedonian queen Arsinoë II (ca. 316-270/268 BCE), who plaved a major role in affaires d'État and was even viewed as a deity (see Elizabeth Carney, Arsinoë of Egypt and Macedon [Oxford: Oxford University Press, 2013]); the Seleucid queen Laodike II (240-190) who obtained political authority through euergetism (see Gillian Ramsey, "The Queen and the City: Royal Female Intervention and Patronage in Hellenistic Civic Communities," Gender and History 23 [November 2011]: 510-27); Cleopatra I who ruled Egypt as a regent for her minor son, Ptolemy VI, for four years (from $180 \mathrm{BCE}$ ) until her death in 176 BCE (see Grace Macurdy, Hellenistic Queens: A Study of Woman-Power in Macedonia, Seleucid Syria, and Ptolemaic Egypt [Baltimore: John Hopkins Press, 1932], 145-7, and the later study by Sarah Pomeroy, Women in Hellenistic Egypt from Alexander to Cleopatra [New York: Schocken, 1984], 23); Cleopatra II who ruled jointly with her siblings and then her daughter (see John Whitehorne, Cleopatras [London: Routledge, 1994], 89-102; 103-20); Cleopatra III who reigned from 116-101 BCE and even obtained the position of priest in the royal cult in $105 \mathrm{BCE}$, which was usually only held by a king (see Macurdy, Hellenistic Queens, 161-70; Pomeroy, Women in Hellenistic Egypt, 24; Whitehorne, Cleopatras, 121-31; 132-48); Cleopatra Berenice III who inherited the Ptolemaic throne in 80 BCE (Whitehorne, Cleopatras, 176-7); and Cleopatra VII who succeeded her father in 51 BCE, initially reigned alone, then jointly with her siblings (Macurdy, Hellenistic Queens, 184-223, Pomeroy, Women in Hellenistic Egypt, 24-8, Jane Rowlandson, ed., Women and Society in Greek and Roman Egypt; A Sourcebook (Cambridge: Cambridge University Press, 1998), 37).

${ }^{2}$ See June Hannam, "Women's History, Feminist History" in

http:/www.history.ac.uk/makinghistory/resources/articles/womens_history.html

${ }^{3}$ This article will only discuss Jewish women in the Second Temple Period, from 586 BCE - 70 CE, and not later rabbinic sources, which is a separate topic in and of itself.

${ }^{4}$ For a discussion of this topic see Joan Wallach Scott, Gender and the Politics of History (New York: Columbia University Press, 1988), 17-20; Gerda Lerner, The Majority Finds its Path: Placing Women in History (Oxford: Oxford University Press, 1979), 14580; Gisela Bock, "Women's History and Gender History: Aspects of an International Debate," Gender and History 1/1 (Spring 1989).
} 
between the lines, against the grain, and looking for what is not written since ancient texts were edited and copied throughout the centuries, and women often were "lost" in this process. ${ }^{5}$

Gender studies started in the 1970s and became established by the 1990s. Using the concept of gender as a tool of historical analysis, it investigates representations of women in male-authored texts as well as gender identities and the difference between the categories of male and female in history. ${ }^{6}$

Both women's and gender studies involve feminist research which "...has brought new perspectives, discovered new data, opened up valuable new areas for enquiry, generated new debates, and simultaneously established itself as an essential component of all forms of holistic analysis." I posit that the fact that such studies in the discipline of Antiquity were undertaken by serious scholars (the majority women), who studied sources in-depth in their original language and drew conclusions based on tested scholarly methods, facilitated the acceptance of these studies by the broader scholarly community.

To return to the specific topic of this article, the issue involved in the study of women in Antiquity is that in the past women were, for the most part, largely invisible in historical texts. Indeed, "[olnce upon a time the history of the ancient classical world was primarily the story of great men and their battles." Nevertheless, royal women and queens such as Arsinoë II, Laodike II, the dynasty of Cleopatra (from Cleopatra I-VII), the Empress Livia and others, represent one of the few categories of women who were mentioned in classical Greco-Roman sources (e.g., Justin's Epitome of the Philippic History of Pompeius Trogus, Cassius Dio's Roman History), inscriptions (e.g., Arsinoë in The Decree of Chremonides) ${ }^{9}$, and art (e.g., busts of Cleopatra II in the Louvre, Paris and other museums). Royal women, however, were the exception. Women in general were usually relegated to second class status by ancient Hellenistic writers. Thus Aristotle declares: "The male is by nature superior, and the female inferior; and the one rules and the other is ruled; this principle of necessity extends to all mankind."

Classical Jewish historical works (mainly Josephus) described queens such as Shelamzion Alexandra, ${ }^{11}$ Mariamme, ${ }^{12}$ Helene of Adiabene. ${ }^{13}$ Yet, the few times that royal women were mentioned as powerful rulers, they often were criticized for taking over what were deemed traditional male roles. This attitude was influenced by a patriarchal outlook based upon the Bible. ${ }^{14}$ For example, Josephus asserts: "It [the Law/Torah] says: a woman is in all things inferior to a man. Accordingly, let her yield/listen, not in order to be maltreated, but so that she be ruled over; for God gave the authority to man." ${ }^{15}$

The fact that ancient texts marginalized women undoubtedly affected the approach of nineteenth- and twentieth-century historians. ${ }^{16}$ Their historical outlook usually manifested a patriarchal

\footnotetext{
${ }^{5}$ See Gillian Clark, "Introduction," in Ian McAuslan, and Peter Walcot, eds., Women in Antiquity (Oxford: Oxford University Press, 1996), 1-16.

${ }^{6}$ For a contemporary discussion of the rise of gender studies and Greco-Roman Antiquity, see Brooke Holmes, Gender, Antiquity and its Legacy (Oxford: Oxford University Press, 2012), 1-13. On approaches to gender in Classical Antiquity, see Lin Foxhall, Studying Gender in Classical Antiquity (Cambridge: Cambridge University Press, 2013), 1-23. On gender, history and religion, see Ross Shepard Kraemer, Unreliable Witness: Religion, Gender and History in the Greco-Roman Mediterranean (Oxford: Oxford University Press, 2011).

${ }^{7}$ Penelope Corfield, "History and the Challenge of Gender History," Rethinking History 1/3 (Winter 1997): 241.

${ }^{8}$ Foxhall, Studying Gender, 1.

${ }^{9}$ See Jane Rowlandson, ed., Women and Society in Greek and Roman Egypt; A Sourcebook (Cambridge: Cambridge University Press, 1998), 26-7.

${ }^{10}$ See Aristotle, Politica, with commentary by Benjamin Jowett, in William D. Ross, ed., The Works of Aristotle (Oxford: Clarendon Press, 1921), 10, 1254a.

${ }^{" S}$ See Josephus, The Jewish War, Volume I: Books 1-2 (Cambridge: Harvard University Press, 1927), \$ 1:107-19 and see Ralph Marcus, trans., Flavius Josephus. Jewish Antiquities, Books XII- XIII (Cambridge: Harvard University Press, 1943), \$ 13:399-432.

${ }^{12}$ See Ralph Marcus, Allen Wikgren, trans., Josephus, Jewish Antiquities, Volume VI: Books 14-15 (Cambridge: Harvard University Press, 1943), \$ 15:237-9.

${ }^{13}$ See Louis Feldman, trans., Flavius Josephus Jewish Antiquities, Book XX (Cambridge: Harvard University Press, 1965), § 1796.

${ }^{14}$ On this topic, see Tal Ilan, "Post-Biblical and Rabbinic Women," in Jewish Women: A Comprehensive Historical Encyclopedia. 1 March 2009. Jewish Women's Archive. Accessed online at: https://jwa.org/encyclopedia/article/post-biblical-and-rabbinic-women ${ }_{1.5}$ See Against Apion 2:201 in Henry St. J. Thackeray, trans., Josephus, The Life, Against Apion (Cambridge: Harvard University Press, 1926), with my emendations to the translation.

${ }^{16}$ Corfield, "History and the Challenge," 4-6, Foxhall, Studying Gender, 6.
} 
double standard, assuming the superiority of men over women in all realms. Elizabeth Carney points out how ancient attitudes affected modern ones:

These ancient prejudices may be further magnified by modern ones. Scholars often assume that Hecatomnid women played no role other than a formal one in rule until their brother-husbands died, and that, even then, they functioned merely as placeholders when they ruled alone...Nothing in our ancient sources suggests that these Hecatomnid women were merely ciphers during their periods of shared rule or that they were considered incompetent when they ruled alone. It continues to be reasonable to believe that the men were the dominant partners in rule, but it is not reasonable to believe that their wives did nothing significant before their husbands' deaths. ${ }^{17}$

Consequently, despite the fact that royal women in Antiquity, especially in Hellenistic society, played a major dynastic role, up until some fifty years ago modern historical accounts either ignored or mentioned them merely as appendages to kings (their wives, mothers, daughters, etc.) due to a legacy of prejudice.

Yet, towards the end of the twentieth and beginning of the twenty-first century, a major change transpired. Inspired by feminist thinkers such as Simone de Beauvoir, a plethora of interdisciplinary studies focusing upon the role of royal and other significant women in Antiquity appeared from the 1970s up until the present time. ${ }^{18}$ This new research has not only affected the content of scholarly studies by adding many newly discovered female figures but has also affected the attitude towards women as historical figures on the one hand, and towards female scholars of Antiquity on the other.

Thus, if almost one hundred years ago Edwyn R. Bevan employed a double standard and criticized a Macedonian queen, Arsinoë II, for behaving cruelly ("a Macedonian princess, with not a little of the tigress ${ }^{\prime 19}$ ) while not criticizing the same behaviour in her male counterparts, today this would not be possible..$^{20}$ In fact, recently there has been a great scholarly interest in Arsinoë II and other queens. ${ }^{21}$ Over 50 years ago William Tarn totally skipped the reign of Queen Alexandra when describing the Hasmonean dynasty. ${ }^{22}$ Yet today this queen has been the topic of dozens of articles and several books. ${ }^{23}$ If women were viewed as non-entitles in Qumran, Sidnie White Crawford, Tal Ilan and Eileen

\footnotetext{
${ }^{17}$ Elizabeth Carney, "Women and Dunasteia in Caria," American Journal of Philology 126 (2005): 77-8.

${ }^{18}$ A chronological list of just some of these studies in the field of Antiquity in general includes Sarah Pomerov, Goddesses, Whores, Wives and Slaves: Women in Classical Antiquity (New York: Schocken Books, 1975); eadem and Helene Foley, eds., Reflections of Women in Antiquity (New York: Gordon and Breach, 1981); Sarah Pomeroy, Women in Hellenistic Egypt from Alexander to Cleopatra (New York: Schocken, 1984); Eva Cantarella, Pandora's Daughters: The Role and Status of Women in Greek and Roman Antiquity (Baltimore and London: John Hopkins Press, 1987); Sarah Pomeroy, ed., Women's History and Ancient History (Chapel Hill: University of North Carolina Press, 1991); Mary DeForest, ed., Woman's Power, Man's Game: Essays on Classical Antiquity in Honor of Joy K. King (Wauconda: Bolchazy-Carducci Publishers, 1993); Elaine Fantham, et al., Women in the Classical World: Image and Text (New York and Oxford: Oxford University Press, 1994); Richard Hawley and Barbara Levick, eds., Women in Antiquity: New Assessments (London and New York: Routledge, 1995); Susan Wood, Imperial Women: A Study in Public Images, 40 B.C. - A.D. 68 (Leiden: Brill, 1999); Shelly Mathews, First Converts (Stanford: Stanford University Press, 2001); Kristina Milnor, Gender, Domesticity, and the Age of Augustus: Inventing Private Life (Oxford: Oxford University Press, 2005); Ross Kraemer, Unreliable Witnesses: Religion, Gender and History in the Greco-Roman Mediterranean (Oxford: Oxford University Press, 2011); Elizabeth Carney, Arsinoë of Egypt; Altay Coșkun and Alex McAuley, eds., Seleukid Royal Women: Creation, Representation and Distortion of Hellenistic Queenship in the Seleukid Empire (Stuttgart: Franz Steiner Verlag, 2016). In the field of Jewish studies the list includes Bernadette Brooten, Women Leaders in the Ancient Synagogue (Chico: Scholars Press, 1982); Amy-Jill Levine, Women Like This: New Perspectives on Jewish Women in the Greco-Roman World (Atlanta: Scholars Press, 1991); Cheryl Brown, No Longer Be Silent: First Century Jewish Portraits of Biblical Women: Studies in Pseudo-Philo's Antiquities and Josephus' Jewish Antiquities (Louisville: Westminster John Knox Press, 1992); Ross Kraemer, Her Share of the Blessings: Women's Religions Among Pagans, Jews and Christians in the Greco-Roman World (New York and Oxford: Oxford University Press, 1992); Athalya Brenner, A Feminist Companion to Esther, Judith and Susanna (Sheffield: Sheffield Academic Press, 1995); Betsy Halpern-Amaru, The Empowerment of Women in the Book of Jubilees (Leiden: Brill, 1999); Tal Ilan, Jewish Women in Greco-Roman Palestine: An Inquiry into Image and Status (Tübingen: Mohr Siebeck, 1995); eadem, Mine and Yours Are Hers: Women's History from Rabbinic Literature (Leiden, New York and Cologne, 1997); eadem, Integrating Women into Second Temple History, (Peabody: Hendrickson, 1999); eadem, Silencing the Queen: The Literary Histories of Shelamzion and other Jewish Women (Leiden: Brill, 2006).

${ }^{19}$ Edwyn R. Bevan, The House of Ptolemy (London: Methuen, 1927), 57.

${ }^{20}$ Grace Macurdy first pointed out this double standard. See Macurdy, Hellenistic Queens, x.

${ }^{21}$ Carney, Arsinoë; eadem, Women and Monarchy in Macedonia (Oklahoma, 2000); eadem, "Women and Basileia: Legitimacy and Political Action in Macedonia,” Classical Journal 90/4 (1995): 367-91.

${ }^{22}$ Tarn's outline of the Hasmonean dynasty does not mention Queen Alexandra at all; it goes from Alexander Jannaeus directly to his two sons, see William Tarn, Hellenistic Civilisation ( $3^{\text {rd }}$ edition, revised by the author and G.T. Griffith) (Cleveland and New York: Meridian Books, 1968), 236-7.

${ }^{23}$ See below, n. 61, for recent studies of Queen Alexandra.
} 
Schuller have shown that women were present at Qumran, both in its literature and in real life. ${ }^{2 t}$ Drawing upon the character of Aseneth in the novella Joseph and Aseneth as a prototype, Ross Shepard Kraemer, Angela Standhartinger and Patricia Ahearne-Kroll have shown how gender stereotypes are reflected in Hellenistic literature. ${ }^{25}$ Finally, the pronouncement in a university class in the 1960s by Elias Bickerman, one of the most prominent scholars of the history of Jews in Antiquity, that "he would never support female students for fellowships, since he believed their scholarly careers would always be aborted by biology - the demands of motherhood," would probably cause his dismissal, or at the very least censure, today. ${ }^{26}$

Let us now survey those scholars who did focus on women in Antiquity. Starting with Grace Macurdy in the 1930s, scholars "discovered" women in general, and queens in particular, who played a major political, religious and economic role. ${ }^{27}$ After a hiatus of forty years, Sarah Pomeroy continued Macurdy's pioneering research on women in classical sources. ${ }^{28}$ Soon sourcebooks and studies appeared, redeeming other important women from oblivion. ${ }^{29}$ By the beginning of the second millennium there was a flood of books on royal women in Antiquity as well as collections of articles. ${ }^{30}$ There have also been evaluations of the changing perspectives relating to the influence of gender in the ancient Greek and Roman worlds." As Coşkun and McAuley have recently noted, "[o]ver the past two and a half decades, the study of royal women has been one of the most dynamic fields of inquiry into the Hellenistic era, and one that has profoundly shifted our perceptions of gender, status, influence, and ability within the broader ancient world. ${ }^{{ }^{2} 2}$ The Oxford University Press is publishing a series of books aimed at filling the lacuna on prominent women in Antiquity. One work in this series, which has already appeared, is Elizabeth Carney's biography of Arsinoë II, a Macedonian queen who reigned together with her husband-brother Ptolemy II from 275-270 BCE. Carney describes in detail Arsinoë II's key political role. ${ }^{3:}$ Other works include biographies of Berenice II, Cleopatra, Clodia Metelli, Faustina I and II, Galla Placidia, Hypatia, Monica, Theodora, Turia, and more biographies are in preparation. ${ }^{3 t}$

${ }^{24}$ Sidnie White Crawford, "Jewish and Early Christian Communities," in James R. Davila, ed., The Dead Sea Scrolls as Background to Postbiblical Judaism and Early Christianity: Papers from an International Conference at St. Andrews in 2001 (Brill: Leiden and Boston, 2003), 177-191; Tal Ilan, "Women in the Qumran and Dead Sea Scrolls," in Timothy H. Lim and John J. Collins, eds., Oxford Handbook of the Dead Sea Scrolls (Oxford: Oxford University Press, 2010), 123-50; Eileen M. Schuller, "What Have We Learned about Women?" in eadem, The Dead Sea Scrolls: What Have We Learned? (Louisville: Westminster John Knox Press, 2006), 80-104.

${ }_{25}$ Ross Shepard Kraemer, When Aseneth Met Joseph: A Late Antique Tale of the Biblical Patriarch and his Egyptian Wife, Reconsidered (Oxford: Oxford University Press, 1998); Angela Standhartinger, "Joseph und Aseneth: Vollkommene Braut und himmlische Prophetin," in Luise Schottroff and Marie-Theres Wacker, eds., Kompendium feministische Bibelauslegung (Gütersloh: Kaiser, 1998), 459-64; Patricia Ahearne-Kroll, "The Portrayal of Aseneth in Joseph and Aseneth: Women's Religious Experience in Antiquity and the Limitations of Ancient Narratives," in Stephen Ahearne-Kroll et al., eds., Women and Gender in Ancient Religions (Tübingen: Mohr Siebeck, 2010), 39-58.

${ }^{26}$ Albert Baumgarte, Elias Bickerman as a Historian of the Jews: A Twentieth Century Tale (Mohr Siebeck, Tübingen, 2010), 160. In response to a question as to when this statement was made, Baumgarten related in an email to me: "I was Bickerman's student from about 1963 until he retired in 1966. I saw him frequently after his retirement but to the best of my recollection he made this remark about female students in class during the years between 1963 and 1966."

${ }^{27}$ Macurdy, Hellenistic Queens; eadem, Vassal-Queens and Some Contemporary Women in the Roman Empire (Baltimore:John Hopkins Press, 1937).

${ }^{28}$ Pomeroy, Goddesses; eadem, Women in Hellenistic Egypt from Alexander to Cleopatra (New York: Schocken, 1984).

${ }^{29}$ Mary Lefkowitz and Maureen Fant, Women's Life in Greece and Rome: A Source Book in Translation (Baltimore: John Hopkins Press, 1982); Rowlandson, Women and Society; John Whitehorne, Cleopatras (London: Routledge, 1994).

${ }^{30}$ Carney, Women and Monarchy, eadem, Arsinoë; Eva D' Ambra, Roman Women (Cambridge: Cambridge University Press, 2006); A. Coșkun and A. McAuley, Seleukid Royal Women: Creation, Representation and Distortion of Hellenistic Queenship in the Seleukid Empire (Stuttgart: Franz Steiner Verlag, 2016), Stephen Ahearne-Kroll et al., eds., Women and Gender in Ancient Religions (Tübingen: Mohr Siebeck, 2010).

${ }^{31}$ For example. Foxhall, Studying Gender; Holmes, Gender; Rosie Wyles and Edith Hall, eds., Women Classical Scholars: Unsealing the Fountain from the Renaissance to Jacqueline de Romilly (Oxford: Oxford University Press, 2016).

${ }^{32}$ See A. Coşkun and A. McAuley, Seleukid Royal Women: Creation, Representation and Distortion of Hellenistic Queenship in the Seleukid Empire (Stuttgart: Franz Steiner Verlag, 2016), 17.

${ }^{3 a}$ Carney, Arsinoë. See also eadem, Women and Monarchy; eadem, "Women and Basileia."

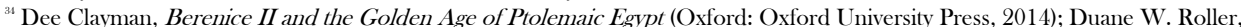
Cleopatra: A Biography (Oxford: Oxford University Press, 2012); Marilyn B. Skinner, Clodia Metelli: The Tribune's Sister (Oxford: Oxford University Press, 2011); Barbara M. Levick, Faustina I and II: Imperial Women of the Golden Age (Oxford: Oxford University Press, 2014); Hagith Sivan, Galla Placidia: The Last Roman Empress (Oxford: Oxford University Press, 2011); Edward Watts, Hypatia: The Life and Legend of an Ancient Philosopher (Oxford: Oxford University Press, 2017); Gillian Clark, Monica: An Ordinary Saint (Oxford: Oxford University Press, 2016); David Potter, Theodora: Actress, Empress, Saint (Oxford: Oxford University 
In the Jewish world, only a handful of books and articles on women in Antiquity were published from 1890 to $1960 .^{3.5}$ In a similar way to general historical studies on royal women in Antiquity, historical studies from the $19^{\text {th }}$ and $20^{\text {th }}$ centuries on royal Jewish women usually contained only a few pages (if any) relating to women. Renewed interest in this topic commenced in the 1970 s, including many general works on women in ancient Jewish history. ${ }^{36}$ Rising interest continued in the 1980 s with books written by prominent scholars (mostly women), such as Bernadette Brooten, Tal Ilan, Ross Shepard Kraemer, Amy-Jill Levine, and others. ${ }^{37}$ As with the general topic of women in Antiquity, after the year 2000 numerous works were published on Jewish women in Antiquity. ${ }^{38}$ The results of a search of the RAMBI catalogue in January 2018 for articles on Jewish women in antiquity reveals some fifty articles but only a handful of articles, many of them by Tal Ilan, deal directly with royal Jewish women. ${ }^{39}$

The theme of Women and Christianity has also been a hot topic, with numerous articles and books being published. ${ }^{40}$ In this connection, Judith Plaskow described one of the problematic issues regarding research on Jewish women in the Greco-Roman period. Inasmuch as many studies were undertaken by Christians who had a particular agenda - a desire to show that Christianity was advantageous for women or even feminist - these scholars claimed that Judaism invented patriarchy thereby turning feminism into one of the means to attack Judaism."

Several journals are devoted to the general topic of women/gender and history such as Arethusa, Gender and History, Women and Gender in Ancient Religions, and Journal of Women's History, along with Jewish-oriented journals that also include historical studies such as Nashim: A Journal of Jewish Women's Studies and Gender Issues, Women in Judaism: A Multidisciplinary e-Journal, etc.

Following this historiographic survey, let us now examine how modern scholarship has contributed to a better understanding of the status, power and realms of influence of individual royal women in Antiquity.

Grace Macurdy was the first to point out that "especially among the Lagids in Egypt the queens remained vigorous and capable at a time when the kings were degenerate and worthless." "Gillian Ramsey describes how the Seleucid queen Laodike II (240-190) exercised euergetism and thereby augmented her queenly authority. ${ }^{43}$ In assessing the posthumous mention of Queen Arsinoë's political influence upon the king in the Decree of Chremonides, Elizabeth Carney postulates that it assumes "that

Press, 2017); Josiah Osgood, Turia: A Roman Woman's Civil War (Oxford: Oxford University Press, 2014). See also Oxford University website for a continuously updated list: https:/global.oup.com/academic/content/series/w/women-in-antiquitywia/?cc=il\&lang $=$ en\&

${ }^{25}$ Starting with Mever Kayserling, Die jüdischen Frauen in der Geschichte, Literatur und Kunst (Leipzig: Brockhaus, 1879); Shai Hurwitz, Ha-ivriyyahve-ha-Yehudiyyah [The Hebrew Woman and Jewess] (Berdichev: Bet Eqed and Yaakov Sheftel, 1891) [Hebrew]; Henry Zirndorf, Some Jewish Women (Philadelphia: Jewish Publication Society, 1892), etc. For a complete survey of the early research on Jewish women, see Ilan, Jewish Women, 2-21.

${ }^{36}$ This includes works such as Leonard Swidler, Women in Judaism: The Status of Women in Formative Judaism (Metuchen, New Jersey: Scarecrow Press, 1976) and Evelyn and Frank Stagg, Women in the World of Jesus (Philadelphia: Westminster Press, 1978).

${ }^{37}$ A chronological list includes Bernadette Brooten, Women Leaders; Léone Archer, Her Price is Beyond Rubies: The Jewish Woman in Greco-Roman Palestine (Sheffield: JSOT Press, 1990); Levine, "Women Like This"; Kraemer, Her Share of Blessings; Brown, No Longer Silent; Ilan Jewish Women, Meir Bar-Ilan, Some Jewish Women in Antiquity (Atlanta: Scholars Press, 1998); Halpern-Amaru, Empowerment of Women, Ilan, Integrating Women.

${ }^{38}$ To name just a few, Athalva Brenner, Are We Amused?: Humour About Women in the Biblical Worlds (London; New York: T \& T Clark International, 2003); Tal Ilan, Silencing the Queen; Ross Shepard Kraemer, Unreliable Witnesses: Religion, Gender, and History in the Greco-Roman Mediterranean (Oxford: Oxford University Press, 2011).

${ }^{39}$ Such as Tal Ilan, "The Attraction of Aristocratic Women to Pharisaism during the Second Temple Period," Harvard Theological Review 88/1 (1995): 1-33; eadem, "Queen Salamzion.” Other articles include van Henten, "Blaming the Women," Knauf, "Salome Alexandra;" Lambers-Petry, "Shelomzion."

40 For example, Mary Rose D'Angelo, "Women Partners in the New Testament" Journal of Feminist Studies in Religion 6/1 (Spring, 1990): 65-86; Ross Shepard Kraemer and Mary Rose D'Angelo, Women and Christian Origins (Oxford: Oxford University Press, 1999); Elizabeth Clark, "Holy Women, Holy Words: Early Christian Women, Social History, and the 'Linguistic Turn'," Journal of Early Christian Studies 6/3 (1999): 413-430; Lisa Bellan-Boyer, "Conspicuous in their Absence: Women in Early Christianity," CrossCurrents 53/1 (Spring 2003): 48-63; Bonnie Thurston, Women in the New Testament: Questions and Commentary (Eugene: Wipf and Stock Publishers, 2004); Patricia Cox Miller, ed., Women in Early Christianity: Translations from Greek Texts (Washington, D.C.: Catholic University of America Press, 2005); and others.

${ }^{41}$ Judith Plaskow, "Christian Feminism and Anti-Judaism," CrossCurrents 28/3 (1978).

${ }^{42}$ Macurdy, Hellenistic Queens, 2.

${ }^{43}$ Ramsey, "Queen and City." 
royal women played a part in family action, success and renown." "John Whitehorne's comprehensive work on the Cleopatra dynasty has focused attention upon queens other than the (in)famous Cleopatra VII, such as, Cleopatra III, who reigned from 116-101 BCE and obtained the position of priest in the royal cult in 105 BCE, an office which was usually only held by a king. was suspected of murdering Augustus and other members of the royal family in order to facilitate her son Tiberius' succession to the throne, has also attracted scholarly inquiry. ${ }^{46}$ An article by Frederick Strickert, which discusses a coin discovered in Israel dated to $30 \mathrm{CE}$ upon which there is an image of the Roman empress Livia, counters the hostile attitude of many scholars towards Livia. Stickert asserts that this coin emphasizes Livia's benevolence, fame and importance. ${ }^{17}$ Beth Severy points out another positive aspect of Livia's reign - she was prominent in restoring shrines and founding cults, which helped redefine the gender role of royal imperial women. ${ }^{18}$ Interestingly, the one biography on Livia is a popular book and not an academic work. ${ }^{19}$

Up until some thirty years ago, scholars of Antiquity often ignored or discounted the only sovereign Jewish queen, Shelamzion Alexandra. ${ }^{30}$ Nevertheless, in the few pages written about Queen Alexandra, the majority of scholars in the nineteenth and most of the twentieth century, such as Joseph Derenbourg, ${ }^{, 11}$ Heinrich Graetz, ${ }^{52}$ Simon Dubnov, ${ }^{53}$ and Joseph Klausner, ${ }^{, 5}$ view her in a positive light as a pious and good queen. This favourable evaluation is due to rabbinic praise of Queen Alexandra. In particular, Sifra B' Hukotai 1:1, implies that the Jewish people were rewarded for observing the commandments with an unusually bountiful and large crop during Queen Alexandra's reign ("grains of wheat became as [large as] kidneys, and grains of barley as [large as] pits of olives, and lentils as [large as] gold denarii"), ${ }^{35}$ and most nineteenth-century historians accepted this as historically reliable. ${ }^{36}$ Henry Zirndorf's biography also paints a dramatic and enthusiastic picture of Queen Alexandra. ${ }^{37}$ Published in 1892, this is one of the first modern works to put Queen Alexandra, along with other women from the Apocrypha, Greco-Roman Period and Talmud, in the limelight. The explanation offered for rabbinic literature's enthusiastic portrait of Queen Alexandra is that such praise is due to the fact that she empowered the Pharisees, who were the forerunner to the sages. ${ }^{\text {ss }}$

\footnotetext{
"Carney, Arsinoë, 93.

${ }^{45}$ Whitehorne, Cleopatras, 121-31; 132-48.

${ }^{46}$ On this matter, see Liebowitz, "Josephus's Ambivalent Attitude towards Women and Power: The Case of Queen Alexandra," Journal of Ancient Judaism 6 (12/2015): 186-7.

${ }^{17}$ Frederick Strickert, "The First Woman to be Portrayed on a Jewish coin: Julia Sebaste," Journal for the Study of Judaism in the Persian, Hellenistic and Roman Period 33/1 (2002): 65-91. See also Rami Arav and Richard A. Freund, eds., Bethsaida: A City by the North Shore of the Sea of Galilee, 3 (Kirksville: Truman State University Press, 2004), 93-114.

${ }^{18}$ See Beth Severy, Augustus and the Family at the Birth of the Roman Empire (New York and London: Routledge, 2003), $232-6$.

${ }^{19}$ Matthew Dennison, Empress of Rome: the Life of Livia (London: Quercus, 2010).

${ }^{50}$ For example, Queen Alexandra merits less than one page in the forty-two page chapter on Simon ben Shetah and King Yannai in Joshua Ephron's study ("Shimon ben Shetach and Alexander Jannaeus," in Menahem Dorman et al., eds., In Memory of Gedaliahu Alon: Essays in Jewish History and Philology [Tel Aviv: HaKibbutz HaMeuchad 1970] [Hebrew]), 147. As previously mentioned, studies on Greek history have also minimized her importance or even skipped her reign when describing the Hasmonean dynasty, see above n. 20.

${ }^{51}$ Joseph Derenbourg, Essai sur l'histoire et la géographie de la Palestine (Paris: Imprimerie impériale, 1867), 111.

${ }^{52}$ Heinrich Graetz, A History of the Jewish People in the Time of Jesus Christ, II (Philadelphia: Jewish Publication Society, 1967); 308-12; originally published as History of the Jews (London: David Nutt, 1891), 47-56.

${ }^{53}$ Semon Dubnov, Vsemirnaya istorila evreiskogo naroda: ot drevneishikh vremen do nastoyashchego (History of the Jews: From Ancient Times to the Present), II (Berlin, 1925), 145-9.

${ }^{5 t}$ Joseph Klausner, "Hasmonean Dynasty," in Ben Zion Netanyahu et al., eds., World History of the Jewish People, 6 (New Brunswick: Rutgers, 1972), 165-78.

${ }^{55}$ Inasmuch as the midrash is located within discussions of the biblical promise of rainfall as a reward for observing the commandments.

${ }^{56}$ Derenbourg, I'histoire et la géographie, 111; Dubnov, Vsemirnaya istorïa, 147; Klausner, "Hasmonean Dynasty," 171; Graetz, History of the Jewish People, 48; Schürer relies upon this tradition to assert that Queen Alexandra's era was "a time of prosperity" and a "golden age." Emil Schürer, A History of the Jewish People in the Age of Jesus Christ, I, new English ed. revised by Geza Vermes et al. (Edinburgh: T \& T Clark, 1973), 231. On the other hand, Jacob Neusner believes that "the story comes long after the 'event' and is pure fantasy." (Jacob Neusner, The Rabbinic Traditions about the Pharisees before 70, Part I [Leiden: Brill, 1971], 89; see also 89-141 for a discussion of the historical veracity of rabbinic traditions about Queen Alexandra and Shimeon ben Shetah.)

${ }^{57}$ Henry Zirndorf, Some Jewish Women (Philadelphia: Jewish Publication Society, 1892), 27-54.

${ }^{58}$ For example, Schürer, History of the Jewish People, I, 231, Graetz, History of the Jewish People, 47-48.
} 
In opposition to the above descriptions, Solomon Zeitlin and Ben Zion Lurie severely criticize Queen Alexandra. ${ }^{39}$ Based upon Josephus' summation of Alexandra's reign (Ant. 13:431-432) and her (mis)identification as the widow of Aristobulus I, Salina Alexandra, they accuse the queen of responsibility for the disintegration of the Hasmonean kingdom. ${ }^{60}$ Yet this criticism also implies that Queen Alexandra possessed significant political authority even before she became a sovereign queen, albeit she is criticized for using it wrongly. Thus, depending upon whether they relied upon rabbinic literature or Josephus's writings, historians in the nineteenth and most of the twentieth century either praised or criticized Queen Alexandra.

From 1989 onwards Queen Alexandra finally received fitting attention and became the focus of numerous scholarly articles, books, M.A. theses and PhD. dissertations. Tal Ilan is the groundbreaking pioneer in offering a feminist analysis of the historical figure of Queen Alexandra and she has been followed by many others. ${ }^{61}$ Ilan believes that Queen Alexandra's gender played a significant role in her decision to allocate power to the Pharisees. ${ }^{62}$ Ilan's foremost conclusion is that rabbinic literature underwent a process of reworking, editing and silencing thereby minimizing Alexandra's contribution to Jewish history. ${ }^{63}$ Ilan also asserts that Queen Shelmazion Alexandra preserved an era of peace for the Jewish people. ${ }^{6 !}$ The discoveries of quasi-historical works at Qumran as well as mishmarot texts provide one trigger for new insights into Queen Alexandra's reign. ${ }^{65}$ Michael Owen Wise hypothesizes that

\footnotetext{
${ }^{59}$ Solomon Zeitlin, The Rise and Fall of the Judaean State: A Political, Social and Religious History of the Second Commonwealth, I (Philadelphia: Jewish Publication Society, 1962), 333-42; Ben Zion Lurie, "From Jannaeus to Herod," in Studies in the Second Temple Period (Jerusalem: Kiryat Sefer, 1974), 159-75 [Hebrew].

${ }^{60}$ For example, Zeitlin asserts: "Jannaeus Alexander had a tragic life. Yet much of the tragedy, which led the country through a long trail of suffering, was actually due to the vicious character of Queen Salome Alexandra. Her mind was occupied with self-preservation, not the interests of the state of Judaea. She devised the plot to assassinate her brother-in-law Antigonus because she feared she would share the fate of her mother-in-law. She made Jannaeus Alexander king although at that time, if she had wished it, she could have reestablished the Commonwealth. She was thus largely responsible for bringing the country to civil war." See Zeitlin, Rise and Fall, 3345 .

${ }^{61}$ Recent studies on Queen Alexandra, feminist and others, include Liebowitz, "Josephus's Ambivalent Attitude;" eadem, "Esther and Alexandra: Paradigms of Queenship in the Septuagint and in Josephus' Writings," Lectio Difficilior 1 (2012); eadem, "The Anomaly of a Sovereign Jewish Queen in the Second Temple Period” (PhD. diss., Hebrew University of Jerusalem, 2011); Kenneth Atkinson, Queen Salome:Jerusalem's Warrior Monarch of the First Century B.C.E. (Jefferson: McFarland, 2012); Ilan, Silencing the Queen. Previous studies include Kenneth Atkinson, "Women in the Dead Sea Scrolls: Evidence for a Qumran Renaissance during the Reign of Queen Salome Alexandra," The Qumran Chronicle 11 (September 2003): 37-56; Tal Ilan, "Shelamzion in Qumran: New Insights" in David Goodblatt, Avital Pinnick and Daniel Schwartz, eds., Historical Perspectives: From the Hasmoneans to Bar Kokhba in Light of the Dead Sea Scrolls (Leiden: Brill, 2001); eadem, Integrating Women; eadem, "Josephus and Nicolaus on Women,” in Hubert Cancik, Hermann Lichtenberger, Peter Schäfer, eds., Geschichte - Tradition - Reflexion, Festschrift für Martin Hengel zum 70. Geburtstag (Tübingen: Mohr Siebeck, 1996), 221-62; eadem, "Queen Salamzion Alexandra and Judas Aristobulus I's Widow: Did Janneaus Alexander Contract a Levirate Marriage?" Journal for the Study of Judaism, 24 (1993): 181-90; Ernst Axel Knauf, "Salome Alexandra and the Final Redaction of Psalms," Lectio difficilior 2 (2009); idem, "Königin Salome Alexandra (76-67 V. Chr.) und die Verfassung des Hasmonäischen Staates," in Historia (Journal of Ancient History) 50 (2001): 163-79; Hanan Eshel, The Dead Sea Scrolls and the Hasmonean State (Jerusalem: Yad Ben Zvi 2004), 122-5 [Hebrew]; Joseph Geiger, "The Hasmoneans and Hellenistic Succession," Journal of Jewish Studies 52 (2002): 1-17; http://www.lectio.unibe.ch; Doris Lambers-Petry, "Shelomzion ha-malka: The Hasmonean Queen and her Enigmatic Portrayal by Josephus," in Internationales Josephus - Kolloquium (Dortmund, 2002), 65-77; Steve Mason, "War 1:107-14: The Pharisees and Alexandra Salome, I," in idem, Flavius Josephus on the Pharisees: A Composition-Critical Study (Leiden: Brill, 1991), 82-115; Eval Regev, The Sadducees and their Halakhah: Religion and Society in the Second Temple Period (Jerusalem: Yad Ben Zvi, 2005), 274-86 [Hebrew]; Samuel Rocca, “'The Book of Judith', Queen Sholomzion and King Tigranes of Armenia: A Sadducee Appraisal," Materia Giudaica 10 (2005): 85-98; James VanderKam, "Pesher Nahum and Josephus," in Alan Avery-Peck et al., eds., When.Judaism and Christianity Began: Essays in Memory of Anthony. J. Saldarini (Leiden: Brill, 2004), 299-311; Michael Owen Wise, Thunder in Gemini and Other Essavs on the History, Language and Literature of Second Temple Palestine (Sheffield: Sheffield Academic Press, 1994), 186-221. See also the following academic studies: Ellen Case, "Salome Alexandra: A Study in Achievement, Power and Survival” (M.A. Thesis, York University, Canada, 1997); Dilys Naomi, Patterson, "Honoured in her Time': Queen Shelamzion and the Book of Judith" (PhD. diss., University of Ottawa, 2002); Penina Stern, "Queen Shelomzion, her Status among Women Rulers of her Period” (M.A. Thesis, University of Haifa, 1999) [Hebrew]; Isaiah Gafni; "The Hasmoneans in Rabbinic Literature," in David Amit and Hanan Eshel, eds., The Days of the Hasmonean Dynasty (Jerusalem: Yad Ben Zvi, 1995), 261-76 [Hebrew]; Joseph Sievers, "The Role of Women in the Hasmonean Dynasty," in Louis Feldman and Gohai Hata, eds., Josephus, the Bible and History (Detroit: Wayne State University Press, 1989), 132-46.

${ }^{62}$ Ilan, Integrating Women, 21-3.

${ }^{63}$ Ilan, Silencing the Queen, 276-80. On Queen Alexandra's portrayal in rabbinic literature, see also Gafni, "Hasmoneans in Rabbinic Literature.”

${ }^{64}$ See Tal Ilan, "Josephus and Nicolaus on Women," in H. Cancik et al., eds., Geschichte - Tradition - Reflexion: Festschrift für Martin Hengel zum 70. Geburtstag (Tübingen: Mohr Siebeck, 1996), 241. It is interesting that both Jewish and non-Jewish queens are credited with maintaining peace.

Such as Wise, Thunder in Gemini; Ilan, "Shelamzion in Qumran;" Eshel, Dead Sea Scrolls; Atkinson, "Women in the Dead Sea Scrolls.”
} 
fragments of calendrical documents formed a "Hasmonean Chronicle" referring to events involving Alexandra in $72 \mathrm{BCE}$ and Hyrcanus' struggle against Aristobulus in late 66 BCE. ${ }^{66}$ European scholars Ernst Baltrusch and Doris Lambers-Petry offer interesting and new perspectives upon Queen Alexandra's role in internal affairs and foreign policy. ${ }^{17}$ According to Baltrusch, the Sadducees' conflict with Alexandra's monarchy was due to their opposition to a political, as opposed to a religious, leader as well as their hostility to a woman fulfilling the functions of a man in religious matters. ${ }^{68}$ Lambers-Petry asserts that two factors helped Alexandra consolidate her power: the Pharisees' support and a strong army. Joseph Sievers, Steve Mason, James VanderKam and Eyal Regev also consider the role of the Pharisees during Queen Alexandra's rule. ${ }^{69}$ Sievers concludes that Queen Alexandra played an "active role in matters of government. ${ }^{{ }^{70}}$ Mason deduces that Queen Alexandra was genuinely pious while the Pharisees only pretended to be so. VanderKam explores the Pharisees' switch of allegiance from opposition to Alexander Jannaeus to support of Queen Alexandra. Regev asserts that Pesher Nahum (4Q169) supports Josephus' description of the Pharisees' control of internal affairs ( War 1:11-112; Ant. 13: 408-409) during Queen Alexandra's reign, in particular the legal realm. Etka Liebowitz maintains that "Alexander Jannaeus apparently realized that his wife [Queen Shelmazion Alexandra] would be a better ruler than either of their sons, and therefore he bequeathed the throne to her."

The above research reveals Queen Alexandra's enormous contribution. It shows that she was a prominent historical figure, a talented and wise ruler with a keen understanding of foreign affairs. She possessed the ability to resolve internal animosities with the Pharisees through the delegation of authority and also to neutralize external threats (a threatened attack upon Judaea by Tigranes) by wise military manoeuvres. These tactics, along with the support of the people, ensured a successful and peaceful reign. Thus, uncovering the role of Queen Alexandra has not only helped us to discover her leadership qualities but has also facilitated a better understanding of other aspects of her era - the role of the Pharisees, the interplay between the religious and secular authority, the attitude of the Qumran sect towards Hasmonean leaders, and more. Indeed, our knowledge of this period would be much poorer without these studies on Queen Alexandra.

Turning to another Jewish queen, research on Queen Helene has focused more on the royal Adiabene household and their conversion to Judaism than on Queen Helene herself. In fact, the focus on Helene's conversion and that of the royal house of Adiabene has obscured any evaluation of her political role. ${ }^{72}$ Nevertheless, Queen Helene's conversion is significant - she was the first of the royal family to convert to Judaism and this could affect our understanding of the conversion of non-Jews to Judaism in general. Helene's piety and journey to Jerusalem to worship at the Temple is praised by both

\footnotetext{
${ }^{66}$ Wise, Thunder in Gemini, 218.

${ }^{67}$ Ernst Baltrusch, "Königin Salome Alexandra (76-67 V. Chr.) und die Verfassung des Hasmonäischen Staates," Historia (Journal of Ancient History) 50 (2001): 163-79; Lambers-Petry, "Shelomzion ha-malka."

${ }^{68}$ Ernst Baltrusch, "Königin Salome Alexandra," 176-178.

${ }^{69}$ Sievers, "Role of Women," Mason, "Pharisees and Alexandra," VanderKam, "Pesher Nahum," Regev, Sadducees.

${ }^{70}$ Sievers, "Role of Women," 136.

${ }^{71}$ Etka Liebowitz, "Josephus's Ambivalent Attitude," 205.

${ }^{72}$ On the royal Adiabene household and their conversion to Judaism, see the following studies: Isaiah Gafni, "The Conversion of the Adiabene Kings in Light of Talmudic Literature," Niv Hamidrashia (1971): 204-12 [Hebrew]; Ilan, "Queen Helene of Adiabene," in Integrating Women, 66-71; Richard Kalmin, "The Adiabenian Royal family in Rabbinic Literature of Late Antiquity," Tiferet le Yisrael (2010): 61-77; Jacob Neusner, "The Conversion of Adiabene to Judaism: A New Perspective," Journal of Biblical Literature 83/1 (March 1964): 60)-6; Lawrence Schiffman, "The Conversion of the Roval House of Adiabene in Josephus and Rabbinic Sources," in L. H. Feldman and G. Hata, eds., Josephus, Judaism, and Christianity (Detroit: Wayne State University Press, 1987), 293-312; Daniel Schwartz, "God, Gentiles, and Jewish Law: On Acts 15 and Josephus' Adiabene Narrative," in Hubert Cancik et al. eds., Geschichte - Tradition - Reflexion, 263-82; one article discusses Quellenkritik: Abraham Schalit, "Evidence of an Aramaic Source in Josephus's Antiquities of the Jews," Annual of the Swedish Theological Institute 4 (1975): 163-18; likewise a dissertation was written on this topic: David Barish, "Adiabene: Royal Converts to Judaism in the First Century C.E.: A Study of the Sources" (PhD. Diss., Hebrew Union College - Jewish Institute of Religion, 1983); on Helene's tomb, see Maximilian Kon, The Tomb of the Kings (Tel Aviv: Dvir, 1947) [Hebrew]. A short article was written on Helene, see Tal Ilan, "Helene, Queen of Adiabene" in Jewish Women: A Comprehensive Historical Encyclopedia (Jewish Women's Archive http://jwa.org/encyclopedia/artcile/helene-q2ueen-of-adiabene, 2009). The most recent comprehensive study on the royal Adiabene household is that of Michal Marciak, "Izates and Helena of Adiabene: A Study on Literary Traditions and History” (PhD. diss., Leiden University, 2012). Marciak's dissertation was subsequently published as a monograph (Wiesbaden: Harrassowitz Verlag, 2014).
} 
Josephus and rabbinic literature..$^{73}$ This also has implications: it was most probably considered one of the attributes of a good Jewish queen and can help scholars better understand the relationship between monarchy and religion.

Interestingly, Queen Helene's death seems to be of more interest than her life, with much significance assigned to her tomb and her palace. ${ }^{21}$ It has been argued that the wrong sarcophagus was identified as that of Queen Helene in the tomb. ${ }^{75}$ Archaeologists have speculated that an impressive large structure discovered in the lower city of Jerusalem might possibly belong to the royal family of Adiabene in general, and in particular one of them may perhaps be the palace of Queen Helene. ${ }^{76}$ Although recently an in-depth study of the royal Adiabene household was published, ${ }^{77}$ no comprehensive scholarly work has focused exclusively on Queen Helene and her actions during her lifetime. A newly published article reveals that Queen Helene had significant political power. ${ }^{78}$ Although she did not become the sovereign queen of Adiabene, she decided who would reign after the death of her husband. Furthermore, her political authority was augmented by the practice of euergetism: she provided food, at a great cost, for the inhabitants of Jerusalem during a famine which won her the admiration of the Jewish people. As with the case of Queen Alexandra, scholarly research on Queen Helene can help us better understand the political situation and religious atmosphere during her era, thereby contributing to a better understanding of Antiquity in general.

Other royal women seldom merit a book in their own right; they are usually part of a larger study or a short article. For example, Tal Ilan describes various Jewish aristocratic women within her magnum opus on women in the Second Temple period as well as in her book on Queen Alexandra; she also discusses Herod's second wife, the Hasmonean Queen Mariamme (along with other royal women) in an article. ${ }^{79}$ Ilan affirms that this is an attempt to "move Jewish women's history out of its prescribed territories [of the home, family or bed] and place it in the public, political, literary and social centres where the nation's consciousness and identity are formed...to integrate Jewish women into Jewish history."

Bezalel Bar Kochva points out that although Doris, Herod's first wife, was involved in major episodes in his life nevertheless she has not been the topic of any real study, and he undertakes to fill this void. ${ }^{81}$ Based on the fact that Josephus uses a Greek name for her, most scholars have identified Doris as a (non-Jewish) Idumean. Thackeray argues that this identification is not clear-cut since many Jewish women had Greek names. ${ }^{82}$ Bar Kokhba points out that Josephus refers to Doris as a Jerusalemite

\footnotetext{
${ }^{73}$ For Josephus's description of this, see Ant. 20:35; 20:49. For rabbinic literature, see MishnahYoma 3:10; Mishnah Nazir 3:6.

${ }^{74}$ On the discovery of Queen Helene's tomb in 1863, see F. de Saulcy, Tombeau de Hélène: reine d'Adiabene (Paris: Claye, 1869); idem, Voyage en terre sainte, II (Paris, 1865). F. De Saulcy is the first explorer to give the tomb this name. On Queen Helene's tomb, see Conrad Schick, "The (So-Called) Tombs of the Kings at Jerusalem," PEFQS 29 (1897): 182-88; Maximillian Kon, Kivrei Ha-Melakhim (Tel Aviv: Dvir, 1947); Amos Kloner, "The 'Third Wall' in Jerusalem and the 'Cave of the Kings'," Levant 18 (1986), 126-9; "Pausanias" in Stern, Greek and Latin Authors, 196-7. The heightened interest in Helene's tomb is not surprising for as Stern notes the fact that "Pausanias puts the tomb of Queen Helene at Jerusalem on the same level [as that of the Mausoleum of Halicarnassus which was considered one of the seven wonders of the world] indicates the tremendous impression it made upon him" (ibid., 197).

${ }^{75}$ See R. Steven Notley and Jeffrey P. García, “Queen Helena's Jerusalem Palace-In a Parking Lot?” Biblical Archaeology Review 40/3 (May/June 2014).

${ }^{76}$ See Doron Ben-Ami and Yana Tchekhanovets, "The Lower City of Jerusalem on the Eve of its Destruction, 70 C.E.: A View from Hanyon Givati," Bulletin of the American Schools of Oriental Research 364 (November 2011): 61-85, esp. 81-2.

7 See Michal Marciak, "Izates and Helena."

${ }^{8}$ Etka Liebowitz, "A New Perspective upon Two Jewish Queens in the Second Temple Period: Alexandra and Helene of Adiabene," in Meron Piotrkowski, Geoffrey Herman and Saskia Doenitz, eds., Sources and Interpretation in Ancient Judaism: Studies for Tal Ilan at Sixty (Leiden: Brill, 2018), 41-65.

${ }^{79}$ Tal Ilan, Integrating Women; eadem, Silencing the Queen, eadem, "King David, King Herod and Nicolaus of Damascus," Jewish Studies Quarterly 5 (1998): 195-240.

${ }^{80}$ Ilan, Integrating Women, 2.

${ }^{81}$ See Bezalel Bar Kochva, "Doris, Herod's First Wife," Cathedra 110 (2003): 5-18 [Hebrew]. For further investigation of Doris within other studies, see Nikos Kokkinos, The Herodian Dynasty, Origins, Role in Society and Eclipse (Sheffield: Sheffield Academic Press, 1998), 208-11; Aryeh Kasher, “On the Character and Origin of the Herodian Dynasty," Cathedra 103 (2001): 5-18 [Hebrew].

${ }^{82}$ On Greek names for Jewish women in in this period, see Tal Ilan, Lexicon of Jewish Names in Late Antiquity, I (Tübingen: Mohr Siebeck, 2002), 313-24.
} 
(War 1:432), and based on this, Thackery's translation of War identifies Doris as Jewish. ${ }^{83}$ Hence, following Bar Kokhba, I believe that we can include her in the list of Jewish royal women. Grounded in an analysis of Josephus' writings, Bar Kokhba deduces that Doris had great authority in royal matters Herod sought her counsel and she was described as "all powerful." ${ }^{{ }^{* 1}}$ Bar Kokhba's analysis sheds more light upon the political role of Jewish queens in Antiquity.

In his study of the Herodian family, Nikos Kokkinos points out that previous research has not given any in-depth attention to the social and family history of the Herodian dynasty. Hence "[s]econdary members of the family [which would include women - E.L.], and their contribution to society have simply been left out. ${ }^{{ }^{85}}$ Kokkinos attempts to fill this lacuna. In regards to women connected with the Herodian dynasty, Kokkinos offers a new chronology for Herod's marriages to his ten wives, he attempts to uncover the origin and genealogy of his lesser known wives and he also attempts to determine when their offspring were born; he also examines Herod's sister and granddaughters ${ }^{86}$ In another study, Kokkinos focuses upon Salome II. ${ }^{87}$ He undertakes to identify which Salome married Aristobulus the king of lesser Armenia and concludes that is was Herodias Salome daughter of Antipas. Kokkinos' conclusion has significant historical implications not only for a correct identification of a female historical figure but also for dating the death of John the Baptist and the crucifixion of Jesus. ${ }^{88}$

In his study of Agrippa I, Daniel Schwartz briefly mentions events connected to Agrippa's wife, Cypros as well as to his sister Herodias. ${ }^{89}$ Yet, more interestingly for our discussion, Schwartz analyses whom Agrippa I's daughters married and maintains that the choice of a marriage partner for his daughters indicates Agrippa's concern (or lack of it) for the Jewish religion. ${ }^{90}$

The studies of Kokkinos and Schwartz demonstrate, once again, that the focus upon aristocratic women affects our understanding of history.

Jan van Henten investigates the leading roles played by the women of Herod's court, in particular Alexandra II, and postulates that through her acts she hoped to reinstate the Hasmonean dynasty. ${ }^{91}$ Furthermore, van Henten asserts that Josephus magnified the wickedness of Alexandra II (and Salome II) in order to elevate King Herod's status. ${ }^{92}$ Once again, new research has shown that acts of royal women have had a direct influence upon historical events.

\section{Conclusions}

Through the study of ancient texts, inscriptions and archaeological remains, scholars have shed light upon both recognized and lesser-known royal women, highlighting their contribution to society and history. Often there is a paucity of sources and an interdisciplinary approach is adopted. At other times, scholars have exposed the double standards used by previous historians in their evaluation of royal women or that of the ancient text itself, which often blamed women for actions when their male counterparts were praised for the very same acts. This is true both for Jewish and non-Jewish aristocratic women.

\footnotetext{
${ }^{83}$ H. St. J. Thackeray, trans., Josephus, The Jewish War (Cambridge: Harvard University Press, 1927), 113. For further discussion of this issue, see Bar Kochva, "Doris," 5-10.

${ }^{84}$ Ibid., 14-16.

${ }^{85}$ Nikos Kokkinos, Herodian Dynasty, 29.

${ }^{86}$ Ibid., 206-45; 264-71.

${ }^{87}$ Nikos Kokkinos, "Which Salome did Aristobulus Marry?" Palestine Exploration Quarterly 118 (1986): 33-50.

${ }^{88}$ Kokkinos, "Which Salome."

${ }^{89}$ Daniel R. Schwartz, Agrippa I: The Last King of Judaea (Tübingen: Mohr Siebeck, 1990), 4, 7-8, 11, 46-48, 50-52, 56-58, 60, $69,120,170,219$.

${ }^{90}$ Ibid., 134.

${ }^{91}$ Jan Willem van Henten, "Blaming the Women: Women at Herod's Court in Josephus's Jewish Antiquities 15.23-231," in Ahearne-Kroll, ed., Women and Gender, 153-75.

${ }^{92}$ In a similar vein, Josephus attacks Queen Alexandra I for ruling instead of a male heir, see Liebowitz, "Josephus's Ambivalent Attitude," 194-5.
} 
What is the importance of the annals of women's and gender studies for scholars today and what can we learn from it?

First of all, a new reading of the lives and actions of royal women can contribute to a better understanding of various political, economic, military and religious developments in Antiquity. If royal women fulfilled the roles of sovereign monarchs, political leaders and policymakers, military commanders and priestesses, then this understanding consequently changes our understanding of ancient monarchies, political alliances, succession to the throne, foreign affairs, religious traditions, and more. Indeed, an accurate understanding of the role on women in Antiquity is vital for a proper understanding of Antiquity in general.

Secondly, as has been shown, there has been a transformation in the study of historical sources relating to aristocratic women. In the past, both ancient and more modern historians have denounced queens for trying to act and rule in the same way as kings. This attitude, however, has changed and now most historians are careful to exclude gender bias from their evaluations of women in Antiquity.

Finally, these understandings can be applied to society today since the present is based upon the past. The legacy of Antiquity is embedded in our present-day thought processes. ${ }^{93}$ Accordingly, the massive change in the attitude towards women in Antiquity in general and towards royal women in particular, including the change in the attitude towards royal Jewish women, impacts upon our current perceptions of women leaders. In her ground-breaking work from the fifteenth century, Christine de Pizan refutes misogynist stereotypes of powerful women and shows that women played important roles throughout history." Pizan's assertion that the focus upon women leaders in Antiquity can inspire contemporary women is just as relevant now as it was 600 years ago. Thus, the fact that today women fulfil leadership roles such as that of a prime minister (albeit a small minority) can be seen not only as a modern innovation but rather as a continuation of an ancient tradition. If the paradigm of an authoritative monarch in Antiquity also includes queens, then this can change the "cultural template for a powerful person" to include women. ${ }^{95}$ This has the potential to assist women in breaking the glass ceiling and achieving many more significant leadership roles.

There are still numerous unexplored topics on women in Antiquity awaiting future generations of scholars. Yet, the foremost educational challenge, which has not yet been fully achieved, is incorporating the topic of women in Antiquity into the general discipline of Antiquity in general and Jewish history in particular, both in scholarly works and in academic textbooks.

\footnotetext{
${ }^{93}$ Holmes, Gender; 1-13.

${ }^{94}$ Christine de Pizan, The Book of the City of Ladies, trans. Earl Richards (New York: Persea, 1982), 256. This is one of the earliest, if not the earliest feminist works analysing misogynist attitudes towards women throughout history, and it includes several Jewish women from Antiquity such as Queen Esther and Mariamme, Herod's wife.

${ }_{95}^{95}$ On this and women's exclusion from power, see Mary Beard, "Women in Power," London Review of Books 39/6 (2017): 9-14, https://www.lrb.co.uk/v39/n06/mary-beard/women-in-power.
} 


\section{BIBLIOGRAPHY}

Ahearne-Kroll, Patricia. "The Portrayal of Aseneth in Joseph and Aseneth: Women's Religious Experience in Antiquity and the Limitations of Ancient Narratives," in Stephen Ahearne-Kroll et al., eds., Women and Gender in Ancient Religions, 39-58. Tübingen: Mohr Siebeck, 2010.

Ahearne-Kroll, Stephen, et al., eds., Women and Gender in Ancient Religions. Tübingen: Mohr Siebeck, 2010.

Arav, Rami and Richard Freund, eds. Bethsaida: A City by the North Shore of the Sea of Galilee. Kirksville: Truman State University Press, 2004.

Archer, Léone. Her Price is Beyond Rubies: The Jewish Woman in Greco-Roman Palestine. Sheffield: JSOT Press, 1990.

Aristotle. Politica, with commentary by B. Jowett. In W. D. Ross, ed., The Works of Aristotle. Oxford: Clarendon Press, 1921.

Atkinson, Kenneth. "Women in the Dead Sea Scrolls: Evidence for a Qumran Renaissance during the Reign of Queen Salome Alexandra." The Qumran Chronicle 11 (September 2003): 37-56.

Atkinson, Kenneth. Queen Salome: Jerusalem's Warrior Monarch of the First Century B.C.E. Jefferson: McFarland, 2012.

Baltrusch, Ernst. "Königin Salome Alexandra (76-67 V. Chr.) und die Verfassung des Hasmonäischen Staates." Historia (Journal of Ancient History) 50 (2001): 163-79.

Bar Kochva, Bezalel. "Doris, Herod's First Wife" [Hebrew]. Cathedra 110 (2003): 5-18.

Baumgarten, Albert. Elias Bickerman as a Historian of the Jews: A Twentieth Century Tale. Mohr Siebeck: Tübingen, 2010.

Beard, Mary. "Women in Power." London Review of Books 39/6 (2017): 9-14. Accessed online at: https://www.lrb.co.uk/v39/n06/mary-beard/women-in-power.

Bellan-Boyer, Lisa. "Conspicuous in their Absence: Women in Early Christianity." CrossCurrents 53/1 (Spring 2003): 48-63.

Ben-Ami, Doron and Tchekhanovets, Yana. "The Lower City of Jerusalem on the Eve of its Destruction, 70 C.E.: A View from Hanyon Givati." Bulletin of the American Schools of Oriental Research 364 (November 2011): 61-85.

Bevan, E. R. The House of Ptolemy. Methuen: London, 1927.

Bock, Gisela. "Women's History and Gender History: Aspects of an International Debate." Gender and History, 1/1 (Spring 1989): 7-30.

Brenner, Athalya. A Feminist Companion to Esther, Judith and Susanna. Sheffield: Sheffield Academic Press, 1995.

Brooten, Bernadette. Women Leaders in the Ancient Synagogue. Chico: Scholars Press, 1982.

Brown, Cheryl. No Longer Be Silent: First Century Jewish Portraits of Biblical Women: Studies in Pseudo-Philo's Antiquities and Josephus' Jewish Antiquities. Louisville: Westminster John Knox Press, 1992.

Cantarella, Eva. Pandora's Daughters: The Role and Status of Women in Greek and Roman Antiquity. Baltimore and London: John Hopkins Press, 1987.

Carney, Elizabeth. "Women and Basileia: Legitimacy and Political Action in Macedonia." Classical Journal 90/4 (1995): 367-91.

Carney, Elizabeth. Women and Monarchy in Macedonia. Oklahoma: University of Oklahoma Press, 2000 .

Carney, Elizabeth. Arsinoë of Egypt and Macedon. Oxford: Oxford University Press, 2013.

Case, Ellen. "Salome Alexandra: A Study in Achievement, Power and Survival." Master's thesis, York University (Canada), 1997.

Clark, Elizabeth. "Holy Women, Holy Words: Early Christian Women, Social History, and the 'Linguistic Turn'.” Journal of Early Christian Studies 6/3 (1999): 413-30. 
Clark, Gillian. "Introduction," in Ian McAuslan, and Peter Walcot, eds., Women in Antiquity, 1-17. Oxford: Oxford University Press, 1996.

Clark, Gillian. Monica: An Ordinary Saint. Oxford: Oxford University Press, 2016.

Clayman, Dee. Berenice II and the Golden Age of Ptolemaic Egypt. Oxford: Oxford University Press, 2014.

Corfield, Penelope. "History and the Challenge of Gender History." Rethinking History, 1/3 (Winter 1997): 241-58.

Coșkun, Altay and Alex McAuley, eds. Seleukid Royal Women: Creation, Representation and Distortion of Hellenistic Queenship in the Seleukid Empire. Stuttgart: Franz Steiner Verlag, 2016.

Cox Miller, Patricia, ed. Women in Early Christianity: Translations from Greek Texts. Washington DC: Catholic University of America Press, 2005.

Crawford, Sidnie White. "Jewish and Early Christian Communities," in James R. Davila, The Dead Sea Scrolls as Background to Postbiblical Judaism and Early Christianity: Papers from an International Conference at St. Andrews in 2001, 177-91. Brill: Leiden and Boston, 2003.

D’Ambra, Eva. Roman Women. Cambridge: Cambridge University Press, 2006.

D'Angelo, Mary Rose. "Women Partners in the New Testament." Journal of Feminist Studies in Religion 6/1 (Spring, 1990): 65-86.

DeForest, Mary, ed. Woman's Power, Man's Game: Essays on Classical Antiquity in Honor of Joy $\mathbf{K}$. King. Waucuna: Bolchazy-Carducci Publishers, 1993.

Dennison, Matthew. Empress of Rome: The Life of Livia. London: Quercus, 2010.

de Pizan, Christine. The Book of the City of Ladies, trans. Earl Richards. New York: Persea, 1982.

Derenbourg, Joseph. Essai sur l'histoire et la géographie de la Palestine. Paris: Imprimerie impériale, 1867.

Dubnov, Semon. Vsemirnaya istorïa evreiskogo naroda: ot drevneishikh vremen do nastoyashchego (History of the Jews: From Ancient Times to the Present), II. Berlin, 1925 [Russian].

Ephron, Joshua. "Shimon ben Shetach and Alexander Jannaeus," in Menahem Dorman et al., eds., In Memory of Gedaliahu Alon: Essays in Jewish History and Philology. Tel Aviv: HaKibbutz HaMeuchad, 1970 [Hebrew].

Eshel, Hanan. The Dead Sea Scrolls and the Hasmonean State. Jerusalem: Yad Ben Zvi, 2004 [Hebrew].

Fantham, Elaine, et al. Women in the Classical World: Image and Text. New York and Oxford: Oxford University Press, 1994.

Foxhall, Lin. Studying Gender in Classical Antiquity. Cambridge: Cambridge University Press, 2013.

Gafni, Isaiah. "The Hasmoneans in Rabbinic Literature," in David Amit and Hanan Eshel, eds., The Days of the Hasmonean Dynasty, 261-76. Jerusalem: Yad Ben Zvi, 1995 [Hebrew].

Geiger, Joseph. "The Hasmoneans and Hellenistic Succession.” Journal of Jewish Studies 53 (Spring 2002): 1-17.

Graetz, Heinrich. A History of the Jewish People in the Time of Jesus Christ, II. Philadelphia: Jewish Publication Society, 1967.

Halpern-Amaru, Betsy. The Empowerment of Women in the Book of Jubilees. Leiden: Brill, 1999.

Hannam, June. "Women's history, feminist history." Accessed online at: http://www.history.ac.uk/makinghistory/resources/articles/womens_history.html

Hawley, Richard and Barbara Levick, eds. Women in Antiquity: New Assessments. London and New York: Routledge, 1995.

Holmes, Brooke. Gender, Antiquity and Its Legacy. Oxford: Oxford University Press, 2012.

Hurwitz, Shai. Ha-ivriyyahve-ha-Yehudiyyah (The Hebrew Woman and Jewess). Berdichev: Bet Eqed and Yaakov Sheftel, 1891 [Hebrew].

Ilan, Tal. "Queen Salamzion Alexandra and Judas Aristobulus I's Widow: Did Janneaus Alexander Contract a Levirate Marriage?” Journal for the Study of Judaism 24 (1993): 181-90. 
Ilan, Tal. Jewish Women in Greco-Roman Palestine: An Inquiry into Image and Status. Tübingen: Mohr Siebeck, 1995.

Ilan, Tal. "The Attraction of Aristocratic Women to Pharisaism during the Second Temple Period." Harvard Theological Review 88/1 (1995): 1-33.

Ilan, Tal. "Josephus and Nicolaus on Women," in Hubert Cancik, Hermann Lichtenberger, and Peter Schäfer, eds., Geschichte - Tradition - Reflexion: Festschrift für Martin Hengel zum 70. Geburtstag, 221-62. Tübingen: Mohr Siebeck, 1996.

Ilan, Tal. Mine and Yours Are Hers: Women's History from Rabbinic Literature. Leiden, New York, and Cologne: Brill, 1997.

Ilan, Tal. "King David, King Herod and Nicolaus of Damascus.” Jewish Studies Quarterly 5 (1998): $195-240$.

Ilan, Tal. Integrating Women into Second Temple History. Peabody: Hendrickson, 1999.

Ilan, Tal. "Shelamzion in Qumran: New Insights," in David Goodblatt, Avital Pinnick and Daniel Schwartz, eds., Historical Perspectives: From the Hasmoneans to Bar Kokhba in Light of the Dead Sea Scrolls, 27-31. Leiden: Brill, 2001.

Ilan, Tal. Lexicon of Jewish Names in Late Antiquity. Volume I. Tübingen: Mohr Siebeck, 2002.

Ilan, Tal. Silencing the Queen: The Literary Histories of Shelamzion and Other Jewish Women. Leiden: Brill, 2006.

Ilan, Tal. "Post-Biblical and Rabbinic Women." Jewish Women: A Comprehensive Historical Encyclopedia. 1 March 2009. Jewish Women's Archive. Accessed online at: <https://jwa.org/encyclopedia/article/post-biblical-and-rabbinic-women>.

Ilan, Tal. "Women in the Qumran and Dead Sea Scrolls," in Timothy H. Lim and John J. Collins, eds., Oxford Handbook of the Dead Sea Scrolls, 123-50. Oxford: Oxford University Press, 2010.

Josephus. The Life, Against Apion, trans. H. St. J. Thackeray. Loeb Classical Library 186. Cambridge: Harvard University Press, 1926.

Josephus. The Jewish War, Volume I: Books 1-2, trans. H. St. J. Thackeray. Loeb Classical Library 203. Cambridge: Harvard University Press, 1927.

Josephus. Jewish Antiquities, Volume V: Books 12-13, trans. Ralph Marcus. Loeb Classical Library 365. Cambridge: Harvard University Press, 1943.

Josephus. Jewish Antiquities, Volume IX: Book 20, trans. Louis H. Feldman. Loeb Classical Library 456. Cambridge: Harvard University Press, 1965.

Kasher, Aryeh "On the Character and Origin of the Herodian Dynasty." Cathedra 103 (2001): 5-18 [Hebrew].

Kayserling, Meyer. Die jüdischen Frauen in der Geschichte, Literatur und Kunst. Leipzig: Brockhaus, 1879.

Klausner, Joseph. "Hasmonean Dynasty," in Ben Zion Netanyahu, et al., eds., World History of the Jewish People, Volume 6. New Brunswick: Rutgers, 1972.

Knauf, Ernst Axel. "Königin Salome Alexandra (76-67 V. Chr.) und die Verfassung des Hasmonäischen Staates." Historia (Journal of Ancient History) 50 (2001): 163-79.

Knauf, Ernst Axel. "Salome Alexandra and the Final Redaction of Psalms." Lectio difficilior 2 (2009). Accessed online at: http://www.lectio.unibe.ch

Kokkinos, Nikos. "Which Salome did Aristobulus Marry?" Palestine Exploration Quarterly 118 (1986): 33-50.

Kokkinos, Nikos. The Herodian Dynasty, Origins, Role in Society and Eclipse. Sheffield: Sheffield Academic Press, 1998.

Kraemer, Ross Shepard. Her Share of the Blessings: Women's Religions among Pagans, Jews and Christians in the Greco-Roman World. New York and Oxford: Oxford University Press, 1992.

Kraemer, Ross Shepard. When Aseneth MetJoseph: A Late Antique Tale of the Biblical Patriarch and His Egyptian Wife, Reconsidered. Oxford: Oxford University Press, 1998. 
Kraemer, Ross Shepard and Mary Rose D'Angelo. Women and Christian Origins. Oxford: Oxford University Press, 1999.

Kraemer, Ross Shepard. Unreliable Witnesses: Religion, Gender and History in the Greco-Roman Mediterranean. Oxford: Oxford University Press, 2011.

Lambers-Petry, Doris. "Shelomzion ha-malka: The Hasmonean Queen and her Enigmatic Portrayal by Josephus," in Jürgen U. Kalms and Folker Siegert, eds., Internationales Josephus Kolloquium, 65-77. Münster: LIT, 2002.

Lefkowitz, Mary and Maureen Fant. Women's Life in Greece and Rome: A Source Book in Translation. Baltimore: John Hopkins Press, 1982.

Lerner, Gerda. The Majority Finds its Path: Placing Women in History. Oxford: Oxford University Press, 1979.

Levick, Barbara. Faustina I and II: Imperial Women of the Golden Age. Oxford: Oxford University Press, 2014.

Levine, Amy-Jill. Women Like This: New Perspectives on Jewish Women in the Greco-Roman World. Atlanta: Scholars Press, 1991.

Liebowitz, Etka. "Esther and Alexandra: Paradigms of Queenship in the Septuagint and in Josephus' Writings." Lectio Difficilior 1 (2012): 1-15.

Liebowitz, Etka. Queen Alexandra: The Anomaly of a Sovereign Jewish Queen in the Second Temple Period. PhD. diss., The Hebrew University, Jerusalem, 2013.

Liebowitz, Etka. "Josephus's Ambivalent Attitude towards Women and Power: The Case of Queen Alexandra." Journal of Ancient Judaism 6 (12/2015): 182-205.

Liebowitz, Etka. "A New Perspective upon Two Jewish Queens in the Second Temple Period: Alexandra and Helene of Adiabene," in Meron Piotrkowski, Geoffrey Herman and Saskia Doenitz, eds., Sources and Interpretation in Ancient Judaism: Studies for Tal Ilan at Sixty, 4165. Leiden: Brill, 2018.

Lurie, Ben Zion. "From Jannaeus to Herod." Studies in the Second Temple Period. Jerusalem: Kiryat Sefer, 1974 [Hebrew].

Macurdy, Grace. Hellenistic Queens: A Study of Woman-Power in Macedonia, Seleucid Syria, and Ptolemaic Egypt. Baltimore: John Hopkins Press, 1932.

Marciak, Michal. "Izates and Helena of Adiabene: A Study on Literary Traditions and History." PhD. diss., Leiden University, 2012.

Milnor, Kristina. Gender, Domesticity, and the Age of Augustus: Inventing Private Life. Oxford: Oxford University Press, 2005.

Mason, Steve. "War 1:107-114: The Pharisees and Alexandra Salome, I," in Steve Mason, ed., Flavius Josephus on the Pharisees: A Composition-Critical Study, 82-115. Leiden: Brill, 1991.

Mathews, Shelly. First Converts. Stanford, Stanford University Press, 2001.

McAuslan, Ian and Peter Walcot, eds. Women in Antiquity. Oxford: Oxford University Press, 1996.

Milnor, Kristina. Gender, Domesticity, and the Age of Augustus: Inventing Private Life. Oxford: Oxford University Press, 2005.

Neusner, Jacob. "The Conversion of Adiabene to Judaism: A New Perspective." Journal of Biblical Literature 83/1 (March 1964): 60-6.

Neusner, Jacob. The Rabbinic Traditions about the Pharisees before 70, Part I. Leiden: Brill 1971.

Notley, R. Steven, and García Jeffrey. "Queen Helena's Jerusalem Palace-In a Parking Lot?” Biblical Archaeology Review 40/3 (May/Jun 2014).

Osgood, Josiah. Turia: A Roman Woman's Civil War. Oxford: Oxford University Press, 2014.

Patterson, Dilys Naomi. "Honoured in her Time: Queen Shelamzion and the Book of Judith." PhD. diss., University of Ottawa, 2002.

Plaskow, Judith. "Christian Feminism and Anti-Judaism." CrossCurrents 28/3 (1978): 89-93.

Pomeroy, Sarah. Goddesses, Whores, Wives and Slaves: Women in Classical Antiquity. New York: Schocken, 1975. 
Pomeroy, Sarah. Women in Hellenistic Egypt from Alexander to Cleopatra. New York: Wayne State University Press, 1984.

Potter, David. Theodora: Actress, Empress, Saint. Oxford: Oxford University Press, 2017.

Ramsey, Gillian. "The Queen and the City: Royal Female Intervention and Patronage in Hellenistic Civic Communities." Gender and History 23 (November 2011): 510-27.

Regev, Eyal. The Sadducees and their Halakhah: Religion and Society in the Second Temple Period. Jerusalem: Yad Ben Zvi, 2005 [Hebrew].

Roller, Duane. Cleopatra: A Biography. Oxford: Oxford University Press, 2012.

Rowlandson, Jane, ed. Women and Society in Greek and Roman Egypt: A Sourcebook. Cambridge: Cambridge University Press, 1998.

Schuller, Eileen. "What Have We Learned about Women?" in eadem, The Dead Sea Scrolls: What Have We Learned? Louisville: Westminster John Knox Press, 2006.

Schürer, Emil, A History of the Jewish People in the Age of Jesus Christ, I. New English ed. revised by G. Vermes et al. Edinburgh: T \& T Clark, 1973.

Schwartz, Daniel R. Agrippa I: The Last King of Judaea. Tübingen: Mohr Siebeck, 1990.

Scott, Joan Wallach. Gender and the Politics of History. New York: Columbia University Press, 1988.

Severy, Beth. Augustus and the Family at the Birth of the Roman Empire. New York and London: Routledge, 2003.

Sievers, Joseph. "The Role of Women in the Hasmonean Dynasty," in Louis Feldman and Gohai Hata, eds., Josephus, the Bible and History, 132-46. Detroit: Wayne State University Press, 1989.

Sivan, Hagith. Galla Placidia: The Last Roman Empress. Oxford: Oxford University Press, 2011.

Skinner, Marilyn. Clodia Metelli: The Tribune’s Sister: Oxford: Oxford University Press, 2011.

Stagg, Evelyn and Frank Stagg. Women in the World of Jesus. Philadelphia: Westminster Press, 1978.

Standhartinger, Angela. "Joseph und Aseneth: Vollkommene Braut und himmlische Prophetin," in L. Schottroff and M.-T. Wacker, eds., Kompendium feministische Bibelauslegung, 459-64. Gütersloh: Kaiser, 1998.

Stern, Menahem. Greek and Latin Authors on Jews and Judaism. Volume II. Jerusalem: Israel Academy of Sciences and Humanities, 1976.

Stern, Penina. "Queen Shelomzion, her Status among Women Rulers of her Period.” M.A. Thesis, University of Haifa, 1999 [Hebrew].

Strickert, Frederick. "The First Woman to be Portrayed on a Jewish Coin: Julia Sebaste.” Journal for the Study of Judaism in the Persian, Hellenistic and Roman Period 33/1 (2002): 65-91.

Swidler, Leonard. Women in Judaism: The Status of Women in Formative Judaism. Metuchen, New Jersey: Scarecrow Press, 1976.

Tarn, William. Hellenistic Civilisation. Third edition, revised by the author and G.T. Griffith. Cleveland and New York: Meridian Books, 1968.

Thurston, Bonnie. Women in the New Testament: Questions and Commentary. Eugene: Wipf and Stock Publishers, 2004.

VanderKam, James C. "Pesher Nahum and Josephus," in Alan Avery-Peck et al., When Judaism and Christianity Began: Essays in Memory of Anthony J. Saldarini, 299-311. Leiden: Brill, 2004.

Van Henten, Jan Willem. "Blaming the Women: Women at Herod's Court in Josephus's Jewish Antiquities 15.23-231," in Stephen Ahearne-Kroll et al., Women and Gender in Ancient Religions, 153-75. Tübingen: Mohr Siebeck, 2010.

Watts, Edward. Hypatia: The Life and Legend of an Ancient Philosopher. Oxford: Oxford University Press, 2017.

Whitehorne, John. Cleopatras. London: Routledge, 1994.

Wood, Susan. Imperial Women: a Study in Public Images, 40 B.C. - A.D. 68. Leiden: Brill, 1999.

Wyles, Rosie and Hall, Edith, eds. Women Classical Scholars: Unsealing the Fountain from the Renaissance to Jacqueline de Romilly. Oxford: Oxford University Press, 2016. 
Zeitlin, Solomon. The Rise and Fall of the Judaean State: A Political, Social and Religious History of the Second Commonwealth, I. Philadelphia: Jewish Publication Society, 1962.

Zirndorf, Henry. Some Jewish Women. Philadelphia: Jewish Publication Society, 1892. 